\title{
13. Coral Bell and the Concert of Power: Avoiding Armageddon
}

\author{
Hugh White ${ }^{1}$
}

Coral Bell gave the title 'A Preoccupation with Armageddon' to the fragment of memoir found among her papers, and began it by recalling the moment she heard that the atom bomb had been dropped on Hiroshima. 'I can even remember the pattern of the hearth-rug on which I was standing when a colleague rushed in with the news', she wrote. 'Perhaps that moment is the reason why so much of my life has revolved around wars and crises; why I have had such a preoccupation with the possibility of Armageddon. Especially how to avoid it' ${ }^{2}$

It is perfectly characteristic of Coral that this short and simple statement should so fully and precisely describe her life's work. Coral Bell was one of the very last of those whose thinking about international relations was shaped by direct and personal experience of hegemonic war, and her life's work was to explore the question about how such wars can be avoided. She looked for answers in the ways states interact with one another, both in the slowly-shifting patterns of their long-term relationships, and in sudden stresses of crisis. She believed the key to preserving peace was to be found in the nature and workings of the international system - the way states communicate with one another, understand one another, and reach and honour agreements with one another, and she devoted her long life and her formidable talents to studying the nature of those communications, understandings and agreements.

She explored how states could reach understandings and agreements which would forestall conflict, and as time passed she became convinced that one model of international understanding offered the best hope for doing that: the concert of power as exemplified by the European order of the century following the Congress of Vienna in 1815. In this essay I will try to trace the evolution of this conviction in her work, relate it to other ideas she developed, and explore her hopes that a concert of power would indeed prove to be the key to avoiding Armageddon in the twenty-first century. But we should start back on that hearth-rug on 6 August 1945.

1 I would like to thank especially my old friends and colleagues, Robert Ayson and Brendan Taylor, for stimulating discussions about the issues covered here.

2 Coral Bell 'A Preoccupation with Armageddon', unpublished memoir, Canberra, 2012, p. 1. 


\section{Preoccupation with Armageddon}

We can picture Coral at that moment: a young woman of twenty-two, serious, shy but confident of her formidable intellect and perhaps also of her charm, quietly but profoundly determined to have a part in shaping the new world that would follow the war, and absolutely sure that avoiding another such war - especially, after Hiroshima, a nuclear war - was more important and more urgent than anything else. She never lost that conviction; never for a moment doubted that contributing to this great task was the whole point of working in the field of international relations, whether as a practitioner or a scholar. She left government for scholarship because she decided that she could contribute more that way, but as a scholar she remained always and absolutely engaged in practical questions of policy. She was never interested in the construction of theories for their own sake, and probably thought that colleagues who found theory more interesting than contemporary questions of policy lacked seriousness, and imagination. Her vivid sense that major war was not just a theoretical possibility but an ever-present danger, and her ability to imagine what such a war would be like and what it would mean, were the mainsprings of her work.

This made her a 'realist' in a specific and significant sense, though one far removed from the academic realism of people like Morgenthau. Hers was the realism of Machiavelli, whose cardinal insight, as Isaiah Berlin explained, was the incompatibility of our most treasured values - 'that ends, equally sacred, may contradict one another'. ${ }^{3}$ Although she was not much given to philosophising at this level of abstraction, Coral clearly understood and accepted this reality. Throughout her work it is clear that she sees that choices have to be made between the preservation of peace and other highly desirable objectives, and she was never in much doubt that peace should take priority. It would not be true to say that Coral believed in peace at any price, but she certainly believed that only something of truly exceptional value was worth a major war.

But unlike most realists Coral was also an optimist. She consistently and perhaps increasingly as time passed believed not just that states could reach and sustain agreements which minimised the risk of major war. She shared the English School's recognition that order and peace could be achieved despite the anarchy of international politics by understandings and cooperation between states. Such agreements were the key to avoiding Armageddon, and hence the perennial focus of her work, and later in her career she saw a concert of power as the most promising form for such agreements to take. Moreover towards the

3 Isaiah Berlin 'The Question of Machiavelli' New York Review of Books, 4 November 1971. www.nybooks. com/50/Machiavelli (accessed 6 August 2013). 
end of her life she became increasingly convinced that an international order based on a 'concert of power' was in fact taking shape. But we have to go back much farther to see the beginnings of her thinking about it.

\section{London}

Coral had an excellent education in history, and there can be little doubt that she knew a good deal about the Concert of Europe well before she began her career as a scholar when she arrived in London in 1951. Over the following years she came to know and be influenced by a remarkable group which included Martin Wight, Hedley Bull and Alistair Buchan, whose approach to the study of international relations was, like Coral's, strongly based on the careful application of historical analogues to current questions. This group were certainly interested in the idea of a 'concert of power', and they referred to it quite often, though not at much length or in much detail. Coral herself seems (from my reading) not to have taken much interest in the 'concert of power' idea herself at this stage, but it seems fair to assume that this is where here ideas about it first evolved.

Coral's London colleagues were certainly struck by the fact that for a century after 1815 there was no hegemonic war between the great powers of Europethat is, no war to establish, or prevent the establishment of, hegemony by any one power. So while there were serious wars in Europe over this time, none approached the catastrophic scale of the Revolutionary and Napoleonic wars that preceded it, or the World Wars that followed it. They believed that Europe avoided hegemonic war because of the nature of the relationships between the great powers themselves, which constituted a distinctive kind of international order. Two things made that order distinctive. One was a matter of style: the way they dealt with one another. As Martin Wight put it: 'the diplomatic system of the Concert maintained standards of good faith, mutual consideration and restraint higher perhaps than at any other time in international history' ${ }^{4}$

The other was a matter of substance: the great power's objectives in dealing with one another. Hedley Bull saw the Concert of Power as an agreement among great powers 'that the maintenance of a general balance of power is a common objective', 5 while Herbert Butterfield wrote, 'The Concert of Europe was in

4 Martin Wight, 'Why is There No International Theory?', in Martin Wight and Herbert Butterfield (eds), Diplomatic Investigations, George, Allen \& Unwin, London, 1966, p. 30.

5 Hedley Bull, The Anarchical Society: A Study of World Politics, Macmillan, London, 1979 p. 114 . Bull offers a much wider definition later in The Anarchical Society (p. 225), where he writes of a concert as an agreement between great powers 'to join forces in promoting common policies throughout the international system as a whole.' His purpose here seems to be to distinguish the agreement underlying a concert from an agreement to divide the system into separate spheres of influence. This seems mistaken: there is no reason why a Concert in the narrower and more useful sense could not be based on a mutually accepted division into spheres of influence. 
origin and essence a common agreement on the principle of the balance of power' ${ }^{6}$ Of course these descriptions lead to questions about the notoriously slippery concept of the 'balance of power' itself, but it is clear that both writers meant in these contexts that the essence of the 'concert of power' was an agreement among the great powers that none of them would try to upset the balance of power by seeking hegemony for themselves. One can also see that there is a close connection between the style and substance of great-power diplomacy under a concert, because the 'high standards', especially of restraint, that Wight mentioned were clearly essential to sustain the mutual forbearance about seeking hegemony that the concert entailed.

These scholars - especially Wight - did not necessarily see the 'concert of power' as a good thing. Wight doubted that it contributed much to the peace of Europe, which he believed owed more to the opportunities for expansion for the great powers outside Europe, ${ }^{7}$ and likened the 'concert' to the later appeasement of fascism, which he said was, 'in a sense a continuation of the old system of the Concert of Europe whereby the great powers settled matters by private bargains among themselves at the expense of small powers' ${ }^{8}$

\section{Kissinger}

The second big influence on Coral's thinking about the 'concert of power' idea seems to have been Henry Kissinger. The first time Coral seems to have focused directly on the concert of power was in her 1977 book The Diplomacy of Détente: The Kissinger Era, which as the title suggests was very much a study of Kissinger's approach to the diplomacy of order-building. Kissinger had of course begun his career with $A$ World Restored about the Congress of Vienna at which the Concert of Europe was created, and the 'concert' idea remained central to his thinking. ${ }^{9}$ The first point to note is that Kissinger's views of the 'concert of power' model were more positive than those of Coral's London colleagues. She wrote of the way Kissinger's policy of détente 'crystallises within itself the central moral tension not only of international politics but of politics in general: the tension between order and justice'. And she quotes approvingly

\footnotetext{
6 Herbert Butterfield, 'The Balance of Power', Diplomatic Investigations, p. 154.

7 Martin Wight, Power Politics, Royal Institutue of International Affairs, London, 1978, p. 42. The opposite could just as easily be true: the great powers were free to expand around the globe because they were secure from hegemonic challenges in Europe.

8 ibid., p. 214. Bull was also alive to the risks of great-power collusion at the expense of smaller powers, especially in the Cold War context between the US and the USSR. See The Anarchical Society, p. 297.

9 See Henry Kissinger, A World Restored: Metternich, Castlereagh and the Problems of Peace, 1812-22, Houghton Mifflin, Boston, 1973.
} 
of Kissinger's resolution of this tension in favour of order, 'The preservation of human life and human society are moral values too' - and for Coral, as for Kissinger, this is what is at stake in avoiding Armageddon. ${ }^{10}$

In exploring the link between Kissinger's academic work and his policy practice Coral offered a very neat account of the 'concert' idea and its relationship to the concepts of balance of power and detente. It deserves to be quoted at some length:

A World Restored is often described as being about the balance of power, but in fact it is about the working of a concert of powers. The distinction between the two is important for an understanding of its relevance to détente. Obviously a balance of power underlay the nineteenth-century concert of powers, or it would not have proved viable, just as a balance of power is now necessary as a foundation of détente, which is not yet a concert of powers. As Castlereagh once said, in a concert system the powers feel a common duty as well as a common interest. A balance of power may be regarded [as] a sort of force of history that tends to assert itself almost automatically in any system of independent sovereignties. A concert of power, on the other hand, must always be a construction of conscious statecraft. ${ }^{11}$

This passage brings out two key aspects of the 'concert of power' idea. First, there is the central question of the relationship between a concert of powers and a balance of power. A balance of power is necessary but not sufficient for a concert. One cannot build a concert unless there is already a balance of power, but much more than that is needed to create a concert. A balance of power system emerges quite spontaneously from the independent calculations of individual states about the best way to preserve their autonomy, but it does not prevent hegemonic war. As Hedley Bull wrote, the balance of power is not a system to prevent war, but to preserve the system of states from hegemony, if necessary though the use of war. ${ }^{12}$ Thus a balance of power system was what remained when the Concert of Europe collapsed in 1914, and the European wars of the twentieth century - including the Cold War-were classic examples of a balance of power system at work to prevent hegemony through war. The point

10 Coral Bell, The Diplomacy of Détente: The Kissinger Era, St. Martin's Press, New York, 1977, pp. 32-33. There is a fascinating and important question here about the role of values in shaping and sustaining a concert of power. Must a concert be based on shared values? Indeed there are two questions; first, is it possible to build a concert without shared values? Second, is it right to do so? Castlereagh seems to suggest that a convergence of values is essential to a concert when he says that they are based on obligations not interests, and Hedley Bull in The Anarchical Society seems to argue that at least a measure of justice is required for a concert to work. I'm not so sure. See Robert Ayson, 'Is Minimal Order Enough?', Hugh White, 'Strategic Parsimony', and Hugh White, 'Response to Commentary on The China Choice', in Security Challenges, vol. 9, no. 1, 2013.

11 Bell, The Diplomacy of Détente, p. 25.

12 Bull, The Anarchical Society, p. 107. 
of a concert is to avoid hegemony without the need for such wars. To do that the balance of power must be maintained not by war but by agreement. This is why a concert 'must always be a construction of conscious statecraft'.

Second, there is the question of what is required to construct the agreements which convert a balance of power into a concert of power. The view attributed to Castlereagh in the passage quoted above suggests that it requires more than simply a shared interest in the prevention of war, but mutual acceptance of higher obligation going beyond that interest. The same idea is hinted at in the idea that the essence of a concert is a higher sense of good faith and obligation as expressed in the quote from Wight above. I'm not sure it's right, and in the end I don't think Coral did either. For her, and for me, the key difference in this respect between a balance of power and a concert of power is not that one is based on interest and the other on obligation, but the nature of the interest being served. The difference is that in a balance of power system the key interest being served for each party is to preserve its independence by avoiding hegemony, whereas in a concert of power each party is also driven by an interest in avoiding war at the same time. To so this they are willing to forgo any chance of achieving hegemony themselves, and undertake instead to respect the independence of all the other parties. A viable concert of power depends on the strength of that undertaking and its credibility with the other parties. The key to creating and sustaining a concert of power is to understand how these undertakings can be created and made credible.

\section{Cold War-Negotiating from Strength}

These insights take us back to some of Coral's much earlier work, where we can see her intense interest in issues which are essential to the idea of a concert, long before she saw them specifically in that context. Her first monograph, Negotiation from Strength: A Study in the Politics of Power, ${ }^{13}$ which was published in 1963, explores an idea that was prevalent in America throughout the 1950s. It was that the US should defer any serious negotiation on accommodation with the Soviet Union until its military position had improved to the point that it would be able to avoid making any substantial concessions to the Soviets in return for a reduction in tensions. Coral says that this is mistaken because US strength did not in fact increase relative to the Soviets over the 1950s, and also, more fundamentally, because America's overriding interests in avoiding war with the Soviets justified substantial concessions to reach an accommodation. The whole book thus focuses on the circumstances under which the US and Soviets might

13 Coral Bell, Negotiation from Strength: A Study in the Politics of Power, Chatto \& Windus, London, 1962, and Alfred A. Knopf, New York, 1963. 
be willing to make the kind of accommodation required to reach a concertlike understanding with one another that would avoid the risk of war, and the imperative to do so.

Only a year or two later Coral saw signs of a more hopeful attitude emerging on both sides of the Cold War divide. In 1964 she wrote of the emergence between the US and the USSR of what she called a 'shadow condominium', the basic function of which is 'their joint management of the central power balance'. ${ }^{14}$ Coral saw this as essentially a crisis-management mechanism in which the central powers acted together to ensure that peace between them was maintained, if necessary at the expense of the interests if smaller powers, and she cited the Cuban Missile Crisis as an early example of the shadow condominium in action. Brendan Taylor is surely correct in seeing in this concept the seeds of a 'concert of power' idea, albeit one that incorporates a great deal of competition along with occasional bouts of cooperation. ${ }^{15}$ What is common between a concert of power and Coral's shadow condominium is the willingness of both powers to sacrifice key interests in order to avoid war with one another. The difference is that in the shadow condominium this willingness only comes into play in times of crisis, whereas in a concert (or one might say, a condominium pure and simple) this willingness frames the management of relationships more or less continually. But it is striking that Coral saw signs of such willingness in $1964 .{ }^{16}$

In the years that followed those signs became much clearer, as the US and USSR moved towards the kinds of mutual understandings that many believed at the time heralded the end of the Cold War. Coral's intense interest in this process was shown in her book on détente in which, as we have seen, she looked very closely at the idea of a 'concert of power'. She was clear that détente did not itself constitute a 'concert' system, but she clearly saw that as one direction in which it might evolve and the image she sketched of that possibility in this book strikingly resembled her ideas of a post Cold War concert of power which emerged in the 1990s. She wrote that an optimistic view of US-Soviet détente in the 1970s could see it as 'a mode of attempting to transmute "a revolutionary order" (which the twentieth century clearly has been and remains) into a "legitimate order" by spinning a sort of web of common interests and arrangements between the revolutionary and status quo powers' ${ }^{17}$ This, she implied, would be a kind of 'concert', but she cautioned that this was not to assume that such an order would be possible in the late twentieth century. She

14 Coral Bell, The Debatable Alliance: An Essay in Anglo-American Relations, Chatham House Essays No. 3, Oxford University Press, London, 1964, p. 111.

15 Brendan Taylor 'A US-China "Shadow Condominium"?' The Strategist, Australian Strategic Policy Institute, 25 October 2012. http://www.aspistrategist.org.au/a-us-china-shadow-condominium/ (accessed 6 August 2013).

16 Others did too, as Robert Ayson has pointed out to me, including Thomas Schelling and Hedley Bull, who saw the Test Ban Treaty of 1963 as evidence for this kind of cooperation.

17 Bell, The Diplomacy of Détente, p. 26. 
quoted Kissinger explaining that many things that made a concert of power possible in the nineteenth Century were not available in the twentieth. 'The stable technology, the multiplicity of great powers, the limited domestic claims and the frontiers which permitted adjustment have gone forever.' ${ }^{18}$ That's a fascinating list of the conditions required for a concert of power, but it may be too demanding, and not all of the conditions turned out to be 'gone forever'. Interestingly for the way Coral's thinking about the concert of power model evolved later, she emphasised that 'any viable concert of power would ... have to be in a world basis'. In a preceding passage she wrote:

Any workable concert system for the late twentieth century, as against the early nineteenth, would have to include some non-European members. One can perhaps see emerging in contemporary international relations what might be called the candidate-members of some prospective world concert of powers, in countries like Brazil or Nigeria or Iran. ${ }^{19}$

Coral dismissed all this as too optimistic for serious policy-making, and maintained her primary focus on the less ambitious and more urgent aim of using détente to make the Cold War safer. But this did not stop her setting down an eerily prescient sketch of how the conditions for her model of a global concert might evolve:

A really optimistic American view of Cold War would presumably hold that the Soviet Union could somehow be made to shrink as a power, allowing Eastern Europe to regain its autonomy and ending any serous military threat and any possibility of the expansion of Soviet influence overseas. But this is a very unrealistic expectation. ${ }^{20}$

\section{After the Cold War}

It is hardly surprising then that when this 'very unrealistic expectation' did nonetheless come to pass, Coral immediately began to argue that the form of international order most likely to replace the bipolar balance of the Cold War was a concert of power. She presented this case first in a short monograph, The Post-Soviet World: Geopolitics and Crises, published in 1992, in which she argued that 'the emerging (or re-emerging) pattern of great power relationships 
is that of a concert of powers, somewhat akin to that after 1815, though of course global rather than merely European, and based on six great powers rather than five'. ${ }^{21}$

Coral had two reasons for thinking that a concert of powers was emerging at this time. The first was her belief-widely shared at the time - that with the end of the Cold War the US-Soviet bipolarity had given way to a multipolar distribution of power in which a number of great powers would all play more or less functionally equal roles. This was of course necessary for the emergence of a concert of power, but it was not sufficient, because a reversion to multipolarity might have produced only reversion to a classic balance of power system. ${ }^{22}$ Her second reason for thinking that a concert of power was then emerging was that she saw evidence that the understandings between great powers necessary for a concert of power were indeed emerging as bipolarity gave way to multipolarity. For this evidence she looked primarily to the functioning of the UN Security Council in the early 1990s, and especially the way the great powers behaved in the Gulf crisis of 1990-91 following Iraq's invasion of Kuwait. The fact that the Security Council had begun to work as originally intended showed, she argued, that the concert of power which had underlain its original design had been revived, albeit with a different membership from that embodied in the Council itself. ${ }^{23}$

In developing this argument Coral gave an interesting account of the idea of a concert of power and how it differs from a balance of power, and the nature of the understandings which make the difference. She wrote:

The difference between a workable concert of powers and an ordinary multilateral balance of power is that a concert system requires consciousness on the part of the central balance decision-makers that (at least for the time being) the common interests of their respective countries vis a vis the rest of the society of states are more important than their competitive interests vis a vis one another. That consciousness can only emerge when adversarial tensions between the central balance powers are at an unusually low ebb: that is, when the element of plausible challenge to the status quo of power distribution is either absent, as it is at the moment, or comes from outside the central balance. ${ }^{24}$

\footnotetext{
21 Coral Bell, The Post-Soviet World: Geopolitics and Crises, Canberra Papers on Strategy and Defence No.98, Strategic and Defence Studies Centre, The Australian National University, 1992, p. 2.

22 Coral had explored how a reversion to multipolarity in Asia would lead to a classic balance of power in an Adephi Paper published in 1968 in which she acknowledged no prospect of a concert emerging. See Coral Bell, The Asian Balance of Power: A Comparison with European Precedents, Adelphi Paper no. 44, International Institute for Strategic Studies, London, February 1968.

23 ibid., p. 6.

24 ibid., p. 4.
} 
There are several notable things about this passage. The first is that it very clearly sees the concert as involving great powers (or 'central balance powers' as she also calls them) alone. She identifies six great powers in the post-Soviet world: America, Russia, Europe, China, Japan and India. ${ }^{25}$ Second, when compared with the account in The Diplomacy of Détente, we can see a shift in Coral's thinking about what drives the great powers to form a concert. The earlier account focuses on the interests they share in avoiding war with one another, whereas this later account instead on the interests they share in managing their relations with, and responding to pressures and threats from, countries outside the group of great powers. Third, she expresses confidence that the adversarial tensions among the great powers are indeed 'at a low ebb', though she acknowledges in a later passage that this might not last, especially as economic relativities shift, though she saw this working more in Europe's favour than in, say, China's. ${ }^{26}$ We will come back to each of these points as we explore how Coral's thinking about the 'concert of power' idea evolved in the last phase of her work.

\section{After 9/11}

Most people, including I think Coral herself, would agree that she had been premature in seeing the emergence of a concert in the early 1990s, because the first requirement for a concert - a bipolar or multipolar distribution of powerdid not in fact eventuate. By the mid 1990s it had become commonplace to see the post-Cold War order not as multipolar but as unipolar, with the US emerging as the uncontested and incontestable leading power. Coral acknowledged this when she returned to exploring the future of the global order in 2005. In a paper for the Australian Strategic Policy Institute titled Living with Giants: Finding Australia's Place in a More Complex World ${ }^{27}$ she acknowledged that America had become the leader in a unipolar global order, but then went on to explain why she thought this was coming to an end, to be replaced by a new multipolar order. 'There is thus, to my mind, an emerging prospect of the transmutation of the present unipolar society of states back into a multipolar one in the foreseeable future ...', she wrote. ${ }^{28}$ And not surprisingly she again predicted that this new multipolar order would function as a concert of powers.

\footnotetext{
25 ibid., pp. $4-5$.

26 ibid., p. 5.

27 Coral Bell, Living with Giants: Finding Australia's Place in a More Complex World, Strategy Report, Australian Strategic Policy Institute, Canberra, April 2005.

28 ibid., p. 14.
} 
Coral developed and elaborated this idea over the following years, most notably in one of her last major publications for the Lowy Institute called The End of the Vasco da Gama Era: The Next Landscape of World Politics. ${ }^{29}$

In these last works Coral saw two forces driving the global system from unipolarity to multipolarity. The less immediate of these, she believed, was the shift in the distribution of power itself, with the rise of a large number of powerful states including many from the developed world, to create what she called a 'company of giants'. Members of her company were characterised primarily by size, and especially size of population, which Coral seems to have considered at this point as more significant than economic weight.

The emerging set of polities for the next central balance range from 'super-size' (China and India at more than a billion each), to those at several hundred million (the US at about 400 million, the EU at maybe 500 million or more, depending on recruitment), with Nigeria, Indonesia, Pakistan and Brazil in the next league. At the lower end of the scale, with a mere 100 million or so, are Russia, Japan, Mexico and others. This would mean a central balance of power, or alternatively a concert of powers, running to twelve or so members, rather like the eighteenth century. ${ }^{30}$

However Coral saw the primary factor driving the replacement of unipolarity by a multipolar order over the next decade or two was the collapse in the legitimacy of US leadership thanks to the mistakes of the Bush Administration in its conduct of the War on Terror. She argued that thanks to follies like the invasion of Iraq, America risked facing the kind of classic anti-hegemonic coalition that had so often merged against leading powers in the past. This, rather than the shift in relate economic weight, was what would prevent America maintaining leadership of a unipolar global order over the next few decades. ${ }^{31}$ She correctly understood that unipolarity, while it lasted, always depended less on America's preponderance of power than on others' willingness to accept rather than contest US primacy.

Of course a simple anti-hegemonic coalition against the US would have produced a multipolar order functioning though a balance of power. Coral however argued that there was good reason to hope that we would see instead the emergence of a global concert of power among this large group of 'giants'. The factor that would drive them to form a concert rather than settle into a balance of power

29 Coral Bell, The End of the Vasco da Gama Era: The Next Landscape of World Politics, Lowy Institute Paper 21, Lowy Institute for International Policy, Sydney, 2007.

30 Bell, Living with Giants, p.29. In her later Lowy paper Coral seemed to step back from this expansive view of the membership of a concert, and limit it to six great powers with a wider group of nine or so major players outside it. See Bell, The End of the Vasco da Gama Era, p. 13.

31 ibid., p. 14. 
system was the threat posed to all of them by what Coral called the 'Jihadist' threat to the global order. ${ }^{32}$ This interesting idea harks back to Coral's views on the nature of concert of power systems which she set out in her discussion of détente thirty years before. Then, as we have seen, she suggested that a concert could be created by the need of the 'central powers' to respond to pressures from outside their group, rather than to restrain rivalry and avoid conflict with one another. The 'Jihadists' would seem to fit this model perfectly, because Coral believed they posed a threat to global order comparable to that posed by the First and Second World Wars and the Cold War. ${ }^{33}$ She saw her 'company of giants' as united by a shared need to respond to this threat effectively, thus creating the conditions for a concert of power between them. Moreover she saw new forms and forums for global multilateral cooperation, like the G20, as both showing that the will existed among the great powers to create a concert, and as offering a path towards realising it. ${ }^{34}$ Her hopes for the G20 were strengthened during the global financial crisis when its meetings were raised to leaders' level and it became, at least for a time, the premier global forum. The prospect that this enhanced G20 would become the basis for a global concert of power was the subject of one of her last, unpublished writings. ${ }^{35}$

There was obviously a lot of optimism in this analysis, but Coral was careful to point out that she was not assuming all would be easy between the great powers; she pointed out that things had hardly been rosy between Europe's great powers in the nineteenth century, and she explained at some length why it would be in each power's interests to support progress towards a concert. ${ }^{36}$ She acknowledged moreover that the most difficult question among the great powers would be the management of relations between the US and China as China's economic and strategic weight grew. She was however optimistic that certain strong opposition would deter China from any hegemonic ambitions, even in its own backyards, ${ }^{37}$ and that America was already well on the way to accommodating China's more modest ambitions for greater regional influence. ${ }^{38}$ This made her hopeful that relations between them could remain manageable, and above all peaceful.

\footnotetext{
32 ibid., p. 20. In her later Lowy paper Coral said that climate change and the proliferation of nuclear weapons would also constitute challenges that would help unify the central powers and drive them to cooperate in a concert, though it seems clear that her main focus was on the 'Jihadist' threat. See Bell, The End of the Vasco da Gama Era, pp. 16-17.

33 ibid., p. 20, 40.

34 Bell, The End of the Vasco da Gama Era, p. 19.

35 Coral Bell, 'The G20 and Multipolarity', unpublished paper, Canberra, 2012.

36 Bell, The End of the Vasco da Gama Era, pp. 17-37.

37 ibid., p. 20.

38 ibid., pp. 33-4. Note there may be a certain tension here between Coral's confidence that China would not be allowed to establish local hegemony, and her assertion that America was already inclined to allow this.
} 


\section{Envoi}

At the end of her long life, then, Coral remained focused on how the international system could best be managed to avoid Armageddon. It is hard not to be beguiled by the blend of determined optimism and hard reasoning which, from first to last, she brought to this task. But we must ask: how far was she right to see in the concert of power the best and perhaps only model for a stable, peaceful international order in the twenty-first century? I think she was much more right than wrong. I have argued elsewhere that a 'Concert of Asia' offers the best and perhaps only way to avoid escalating strategic rivalry between Asia's great powers over coming decades, for reasons which have much in common with Coral's and owe much to her analyses. ${ }^{39}$ But there are two ways in which I'd differ from her analysis and predictions.

First, it seems to me that an effective concert must be smaller than Coral sometimes envisaged - only the great powers are involved ${ }^{40}$ — and that it is much more likely to be a regional than a global arrangement, because the redistribution of wealth and power now underway is dismantling the global strategic system of recent centuries. Second, and more fundamentally, I think Coral was too optimistic about what would be required for a concert of power to evolve, and what the chances are of that happening. I do not think the 'Jihadist' threat - or the other unifying external challenges - has or will prove big enough to overshadow the tensions inherent between the region's major powers, and especially between the US and China.

That is, firstly, because I think the shift in relative economic and strategic weight between them is more fundamental and thus more disruptive to the established patterns of their relationship than Coral allows. By calling this shift 'the end of the Vasco da Gama era' Coral leaves us in no doubt that she sees how big this is. But even so her focus on demographics rather than economics does lead her to overlook just how much more important China's rise is to the redistribution of power than the other trends she mentions. This also leads her to underestimate the scale of the challenge it poses to the United States' power in Asia and its role in the Asian order. And secondly, this is because she overstates both the United States' and China's willingness to accommodate one another's very different expectations about their future relationships. For both countries these weigh far more in their thinking than the 'Jihadist' threat, or the global financial crisis, or anything else. They go to deep questions of national self-identity. Coral is absolutely right to see a mutual accommodation of these differences as entirely

39 Hugh White, The China Choice: Why America Should Share Power, Black Inc., Melbourne, 2012.

40 ibid., p. 141. 
possible, and as offering a robust foundation for a stable concert of power system if it can be achieved. But she underestimated how hard it will be, and how likely is failure.

The challenge she has left us is to prove her optimism justified by seeing what can be done to improve the chances of building a concert of power in Asia. That means exploring what exactly would be required to achieve an accommodation between the US and China - and Asia's other great powers - that would provide the basis for peace. One might say that the best way to honour Coral's life and work is to throw ourselves into that task, because she was right: avoiding another hegemonic war-especially a nuclear war-remains more important and more urgent than anything else. 
This text taken from Power and International Relations:

Essays in honour of Coral Bell, edited by Desmond Ball and Sheryn Lee, published 2014 by ANU Press, The Australian National University, Canberra, Australia. 